\title{
持続的な抗菌性を付与する表面処理技術の開発
}

\author{
唐澤 慧記 ${ }^{\mathrm{a}}$, 萬 隆行 ${ }^{\mathrm{b}}$, 佐古 弘志 ${ }^{\mathrm{b}}$, 内田 淳一 ${ }^{\mathrm{b}}$ \\ a 小林製薬株) 日用品事業部 新分野推進グループ ( ⿳ 5 511-0045 大阪府大阪市中央区道修町 4-4-10) \\ ${ }^{b}$ 日本パーカライジング株) 総合技術研究所 第四研究センター（～254-0012 神奈川県平塚市大神 2784)
}

\section{Development of Surface Treatment Giving Sustained Antibacterial Properties}

\section{Satoki KARASAWA ${ }^{\text {a }}$, Takayuki YOROZU ${ }^{\text {b }}$, Hiroshi SAKO ${ }^{\text {b }}$ and Junichi UCHIDA ${ }^{\text {b }}$}

\author{
${ }^{a}$ Household Division Business Development Section, Kobayashi Pharmaceutical Co., Ltd. (4-4-10, Dosho-machi, Chuo-ku, Osaka-shi, \\ Osaka 541-0045) \\ ${ }^{\mathrm{b}}$ Central Research Laboratories R\&D Center IV, Nihon Parkerizing Co., Ltd. (2784, Ohkami, Hiratsuka-shi, Kanagawa 254-0012)
}

Keywords : Antibacterial Property, Coating Film, Surface Treatment, Silane Coupling Agent

\section{1. はじめに}

日本においては，高度経済成長から始まる消費社会の拡大 により，一般消費者の生活ニーズにきめ細やかに対応する製 品が数多く開発された。その結果として, 消費社会の飽和を 迎えていると言われている昨今，国連総会で採択された「持 続可能な開発目標 $(\mathrm{SDG}) 」 に$ 代表されるように, 持続可能 な生産消費形態の形成が求められてきている。このような社 会背景の変化を受けて，レジ袋の有料化によるエコバッグの 普及を筆頭に，使い捨てることが当たり前であった製品カテ ゴリーにおいても, 繰り返し使用など, 1 人の生活者が 1 つ の製品を使用する時間が長くなると予想される。

一方, 製品の繰り返し使用や長期間使用は, 人や環境由来 の微生物污染のリスクが相対的に高まることが考えられる。 微生物は, 生命活動や生態系の維持, 食品や化学品などの産 業活用など, 今も昔も人類の生活にとって不可欠な存在であ る。しかし, 微生物の代謝によるニオイの発生やカビの繁殖 などによる「不潔」, 病原性微生物による感染症などの「不 衛生」, 微生物による食品の変質などの「腐敗」等, 私たち の生活における問題を引き起こすことも，また事実である。 そのため, 持続可能な生産消費を考える上では, 微生物によっ て生じるリスクを適切にコントロールし, 微生物との共生を 模索していく方法が重要になると考えられる。

微生物のコントロールを考える場合, 私たちが生活する空 間や使用する製品を形成する表面への機能付加は有用な方法 の 1 つとして考えられる。素材表面に抗菌機能を付加する技 術に関しては, 繊維分野での開発事例が多く見られ, 抗菌防 臭衣類などに実装化されることにより，使用者の生活の質の 向上，および，使用者が快適に製品を使用できる製品寿命の 延命に寄与している。また, 繊維以外に目を向けた場合, 樹 脂・ガラス・金属など, 多種多様な化学特性を有する硬質表 面に広く対応できる抗菌表面処理技術の開発は, 持続可能な
生産消費を実現させていく上で求められる技術の 1 つである と考えられる。

\section{2. 持続的な抗菌性能の考え方}

すでに様々な抗菌加工製品が上市されており, その加工方 法は, 抗菌剂を素材自体に練り込む方法と, 表面処理によっ て素材表面に固定化させる方法に大別される。前者は, 素材 自体に練り込まれていることから優れた耐久性を示しやすい ものの, 表面積に対して体積が大きい部材ほど内部に埋もれ てしまう抗菌材料の割合が多くなる。また，金属など，練り 込み自体が行えない部材も存在することや, 生産数が少ない 製品に活用しにくいことが欠点として挙げられる。

一方，後者は，一般的に前者の長所 / 短所を反転させた特 徴を有するため, 短所とされる耐久性を克服した抗菌性を示 す表面処理技術の開発は, 様々な抗菌加工製品の開発に繋が ると考えられる。また, 抗菌加工製品が使用される環境に応 じて, 耐摩耗性, 耐水性, 耐薬品性など, 求められる持続性 の項目は異なってくる。そのため, 表面処理による抗菌加工 技術は, その使用環境に応じた抗菌剂の選定と最適な被膜設 計が必要となる。

\section{1 先行研究事例}

素材表面に対し, 共有結合の形成を利用して抗菌成分を固 定化する薬剤は固定化殺菌剂と称されており, 薬剤の構造よ りポリマー型とシリコン型の 2 種に分類されている ${ }^{1)}$ 。ポリ マー型に関する先行研究事例として, 鈴木らはポリマー型第 4 級アンモニウム塩を抗菌剤として選定し, 表面処理被膜と なる樹脂成分と架橋剤を組み合わせることにより耐水性を有 する抗菌性能の付与を狙った研究について報告している ${ }^{2)}$ 。

72 時間の流水耐久試験後において, 開発品のポリマー型 第 4 級アンモニウム塩の残存率は $100 \%$ と良好な值であった ものの, イソチアゾリン系抗菌剤を添加した比較品 B は 66\% とやや低い值であった。また, 低分子量型第 4 級アン 
モニウム系抗菌剤を添加した比較品 $\mathrm{C}$ の場合, 抗菌剤の残 存率は $12 \%$ と更に低い值であった。各水準には同量の架橋 剤が添加されているものの, 抗菌成分の高い耐水残存率を示 した水準は開発品のみであった(図 1)。

また，流水耐久試験前の全ての水準において抗菌活性值は 5.0 以上と高い抗菌性能を示していたが, 流水耐久試験後に は比較品 B および比較品 C の抗菌活性值は大きく低下した。 一方，ポリマー型第 4 級アンモニウム塩を添加した開発品は 流水耐久試験後も流水耐久試験前の值を維持した (図 2)。

上記の結果は, 抗菌成分の耐水残存率が高い水準は抗菌活 性值も高い值を示しており，抗菌成分を固定化するためには 適切な抗菌剤の選定と表面処理被膜の設計が重要であること を示している。

\section{2 抗菌剤について}

小林製薬は，ブルーレットなどの製品開発を通して環境菌 の制御方法・評価技術の研究を積み重ねてきており, 近年で は抗菌・抗カビ・抗ウイルス加工のニーズを抱える産業に持 続性抗菌剂 KOBA-GUARD (コバガード)の提供を行っている。

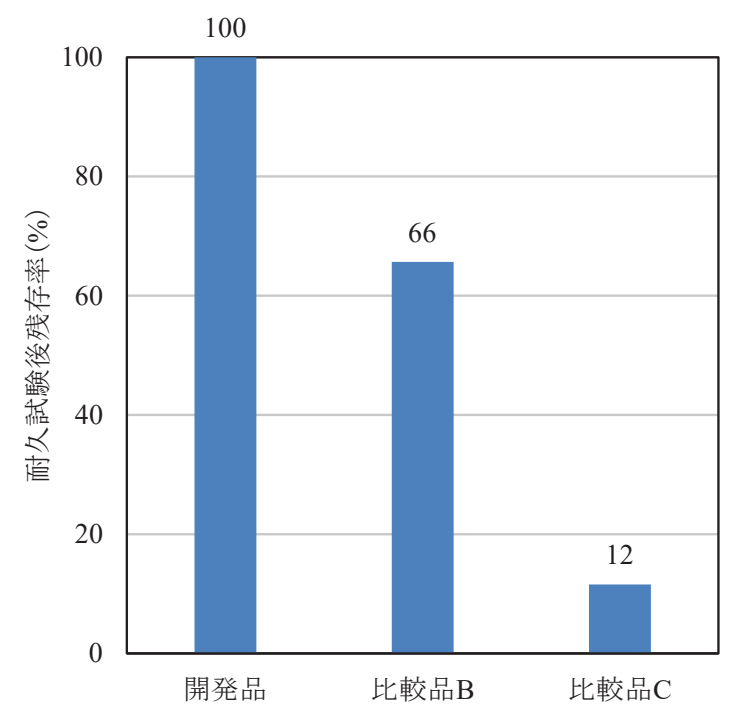

図 1 流水耐久試験後の抗菌剂残存量

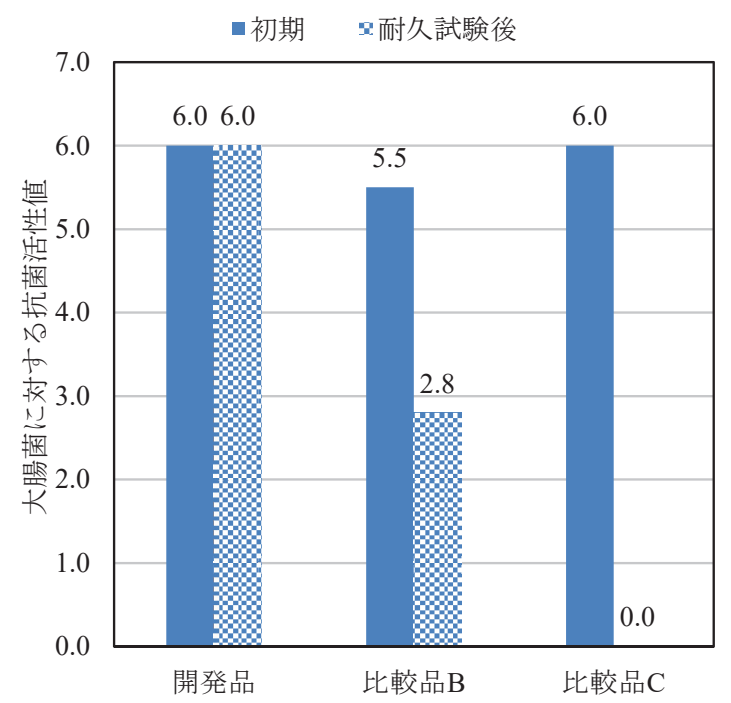

図 2 流水耐久試験後の抗菌性試験結果
KOBA-GUARD は第 4 級アンモニウム塩を分子構造に有する シランカップリング剂型化合物 (以下, Si-QAC) を有効成分 としている抗菌加工剤であり, 前述の固定化殺菌剤のシリコ ン型に該当する成分でもある ${ }^{1)}$ 。Si-QAC は, アルコキシシ リル基が加水分解して生じる水酸基を介した脱水縮合反応に よる共有結合の形成により, 対象表面に固定化され, 細菌, 真菌に対して幅広い抗菌スペクトルを示すことが知られてい る $^{3)}$ 。

一方，抗菌成分の中で，Si-QACのようにシリル基を同一 分子内に有している抗菌成分は限定的であるため，シリル基 を持たない化合物を対象表面に固定化することが可能となる と, 抗菌加工の幅が広がると考えられる。抗菌成分がシラン カップリング反応により架橋され得る官能基を有している場 合，シリル基を有する化合物と共に加工することで，対象表 面に固定化することが可能と考えられる。この場合, 固着状 態で抗菌活性を発揮するために, 対象微生物の細胞内部に侵 入すること無く抗菌活性を示す化合物を選択する必要がある が, 細胞表層タンパク質の機能阻害で抗菌効果を発揮する銀 などの無機物はこの条件を満たすと考えられる ${ }^{4)} 。$

\section{3 表面処理技術}

日本パーカライジングは, 自動車産業や鉄鋼産業など様々 な産業に向けて，金属材料の防錆用途などを目的とした表面 処理剤を提供している。特に, 建材や家電などに使用される 材料に対し，環境負荷物質として懸念される 6 価クロムなど の成分を配合しない表面処理技術として，シランカップリン グ剂を主成分とした表面処理剂を提供している。このシラン カップリング技術から得られる被膜は薄膜で低温の乾燥条件に おいても素材との界面強度, 接着力などが強固であり, かつ 繊維や硬質などの広範囲の素材表面に固着できる技術である。

我々はこれらの技術を用いることにより，持続的な抗菌性 能を付与する表面処理技術の開発を進めている。ここでは, 硬質材料および繊維材料における抗菌性付与に関する研究事 例を以下に紹介する。

\section{3．実験方法}

\section{1 硬質材料の抗菌処理および評価方法}

\section{1. 1 硬質用の表面処理剤の概要}

今回用いた表面処理剤は抗菌剂である Si-QAC と被膜の主 成分となるバインダー成分で構成している。各種バインダー 成分の概要を表 1 に示す。なお, 表面処理剤中の Si-QAC 濃 度は，各実験結果に記載した割合となるように配合した。

表 1 硬質用表面処理剤検討に用いたバインダー 成分の概要

\begin{tabular}{c|l}
\hline \multicolumn{1}{c|}{ 名称 } & \multicolumn{1}{c}{ 特徵 } \\
\hline オリゴマー A & $\begin{array}{l}1 \text { 液硬化型 } \\
\text { シリコーンオリゴマー }\end{array}$ \\
\hline \multirow{2}{*}{ オリゴマー B } & $\begin{array}{l}\text { 1 液硬化型 } \\
\text { シリコーンオリゴマー }\end{array}$ \\
\hline & 2 液硬化型 \\
オリゴマーC & 有機樹脂変性 \\
& シリコーンオリゴマー \\
\hline
\end{tabular}




\section{1.2 評価材の作製方法}

表面処理剂にて処理したフロートガラス板(株パルテック 製)もしくはステンレス板(SUS 304 ：(株パルテック製)を評 価材とした。評価材を作製する際は，アルカリ脱脂剤などを 用いて表面洗浄した後, バーコーターを用いて表面処理剤を 塗工し，加熱乾燥させることで固着させた。

3. 1.3 抗菌性の評価方法

JIS Z 2801：2012（フィルム密着法）に倣い，大腸菌 (Escherichia coli NBRC3972), 肺炎桿菌 (Klebsiella pneumoniae NBRC 13277)に対する抗菌性を評価した。なお，試験実施時 には，対照試料として未加工のガラスパネルを用い，接種培 地としては $1 / 20 \mathrm{NB}$ 培地を用いた。

3. 1.4 被膜中の元素分布分析方法

X 線光電分光法 (XPS)により，最表層から $180 \mathrm{~nm}$ までを 段階的に深さ方向元素分析を実施した。

3. 1. 5 被膜の機械的性質の評価方法

・テープ剥離試験(クロスカット法)

JIS K 5600-5-6 (付着性)を参考とし，被膜の付着性を評価 した。なお，試験実施には， $1 \mathrm{~mm}$ 間隔のカッターガイドを 用いて縦横垂直に 11 本ずつ計 100 マスの切り込みを入れ, セロハン粘着テープの付着・剥離後に残った被膜の数にて付 着性を評価した。

・鉛筆硬度試験

JIS K 5600-5-4 (引っかき硬度)を参考とし，被膜の硬度を 評価した。なお，試験実施には，鉛筆として Hi-uni（三菱鉛 筆(侏)製)を用いて，鉛筆の角度が $45^{\circ}$ ，負荷荷重が $1 \mathrm{~kg}$ とな るようにして行った。

・耐摩耗性

接触部にガーゼ (日進医療器(株製)を 8 枚重ねで当て, $500 \mathrm{~g}$ の荷重を加えて摺動させることで被膜の耐摩耗性を評 価した。なお，剥離した被膜の影響を除くため，ガーゼは 100 回毎に新しいものと交換した。また, 耐溶剤性を調べる ため, エ夕ノール $(\mathrm{EtOH})$, および, メチルエチルケトン (MEK) を含浸させたガーゼを用いて摺動を行った。

表 2 繊維用表面処理剂検討に用いた化合物の概要

\begin{tabular}{l|l}
\hline \multicolumn{1}{c|}{ 名称 } & \multicolumn{1}{c}{ 特徴 } \\
\hline シラン化合物 $\mathrm{A}$ & 水溶性シラン \\
\hline シラン化合物 $\mathrm{B}$ & 水溶性シラン \\
\hline \multirow{2}{*}{ シラン化合物 C } & $\begin{array}{l}\text { シラン化合物 } \mathrm{A} \text { と比較して } \\
\text { ポリマー化度が高い } \\
\text { シリコーンエマルジョン }\end{array}$ \\
\hline 架橋剤 & ブロックイソシアネート系 \\
\hline
\end{tabular}

表 3 抗菌性評価に用いたバインダー組み合わせ

\begin{tabular}{c|c}
\hline \multicolumn{1}{c|}{ 名称 } & 特徵 \\
\hline 処理液 $\mathrm{a}$ & 銀成分+シラン化合物 $\mathrm{A}$ \\
\hline 処理液 $\mathrm{b}$ & $\begin{array}{c}\text { 銀成分 }+ \text { シラン化合物 } \mathrm{A} \\
+ \text { シラン化合物 } \mathrm{B}\end{array}$ \\
\hline 処理液 $\mathrm{c}$ & $\begin{array}{c}\text { 銀成分 }+ \text { シラン化合物 } \mathrm{A} \\
+ \text { 架橋剤 }\end{array}$ \\
\hline 処理液 $\mathrm{d}$ & 銀成分 + シラン化合物 $\mathrm{C}$ \\
\hline
\end{tabular}

\section{2 繊維の抗菌処理および評価方法}

\section{2. 1 繊維用表面処理剂の概要}

今回用いた表面処理剤は抗菌剂である銀成分と被膜のバイ ンダー成分および架橋剤などで構成している。各化合物の特 徵を表 2 に示す。試験においては, 銀成分と各種バインダー を組み合わせ，各バインダーの効果を確認した。バインダー の組み合わせを表 3 に示す。

\section{2. 2 評価材の作製方法}

表面処理剤を用いて，抗菌活性を有さないポリエステル $100 \%$ ニット $\left(245 \mathrm{~g} / \mathrm{m}^{2}\right)$ を加工した生地を評価材とした。ポ リエステル生地を加工する際は, 表面処理薬剤に生地を浸し て絞り， $105{ }^{\circ} \mathrm{C}$ に予備乾燥を行った後， $160{ }^{\circ} \mathrm{C} に 2 ~ 2$ 分間 熱処理を行った。

\section{2.3 抗菌性の評価方法}

JIS L 1902：2015 (菌液吸収法)を参考とし，大腸菌に対す る抗菌性を評価した。なお，試験実施時には，対照試料とし て抗菌試験用標準布 (綿：一般社団法人 繊維評価技術協議会 より購入)を用い, 接種培地としては非イオン界面活性剂 $0.05 \%$ 添加 $1 / 20 \mathrm{NB}$ 培地を用いた。

\section{2.4 洗濯処理方法}

一般社団法人 繊維評価技術協議会 SEK マーク繊維製品の 洗濯方法(標準洗濯法，吊り干し)にて処理した。

\section{4. 結果および考察}

\section{1 硬質の抗菌性能について}

4. 1. 1 Si-QAC を固着させたガラスパネルの抗菌性評価 オリゴマーA を用いて Si-QAC を固着させた評価材の，肺 炎桿菌に対する抗菌性試験結果を図 3 に示す。なお，各水準 における被膜中の Si-QAC 量を 5 段階で調製し, 加工時の加 熱乾燥条件は $140{ }^{\circ} \mathrm{C} に 20$ 分とした。

その結果，被膜中に Si-QAC を $2.85 \%$ 以上含む水準では良 好な抗菌活性を示したものの， $0.60 \%$ 以下の水準では，オリ ゴマーAのみで加工した評価材と同程度の抗菌活性を示す 結果となった。

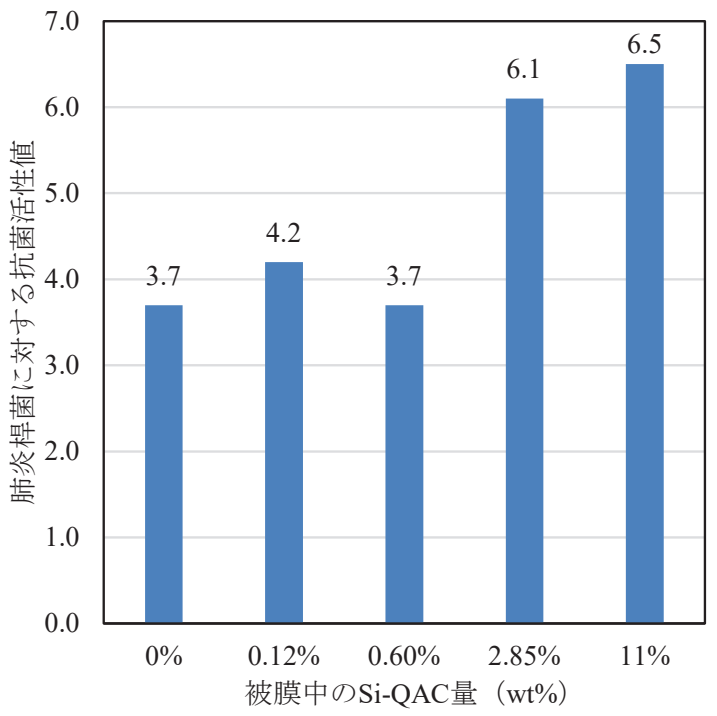

図３オリゴマーA を用いて加工したガラスパネルの 肺炎桿菌に対する抗菌性試験結果 
次に, Si-QAC を固定化する際のバインダー成分による抗 菌活性への影響を評価するために，オリゴマー B および $\mathrm{C}$ を用いて Si-QACを固着させた評価材の抗菌性試験結果を 図 4 および図 5 に示す。また, 熱乾燥条件は, オリゴマーB は $180{ }^{\circ} \mathrm{C}$ にて 20 分, オリゴマー $\mathrm{C}$ は $140{ }^{\circ} \mathrm{C} に て ~ 20$ 分とし, 被膜中における Si-QAC 濃度は, 図 3 にて抗菌活性が得られ た $11 \%$ 程度とした。

その結果, オリゴマー C を用いた評価材は抗菌活性を示 したものの，オリゴマーBを用いたものは抗菌活性を示さ なかった。なお，Si-QAC は肺炎桿菌よりも大腸菌に対して 抗菌活性を示しやすいことが分かっている。

4. 1. 2 Si-QAC を含む被膜構造

細菌に対する抗菌活性は被膜の最表層で発現することから， 被膜における抗菌剤の分布や最表層の組成に関する情報は重 要である。オリゴマー A もしくはオリゴマー B を用いて Si-

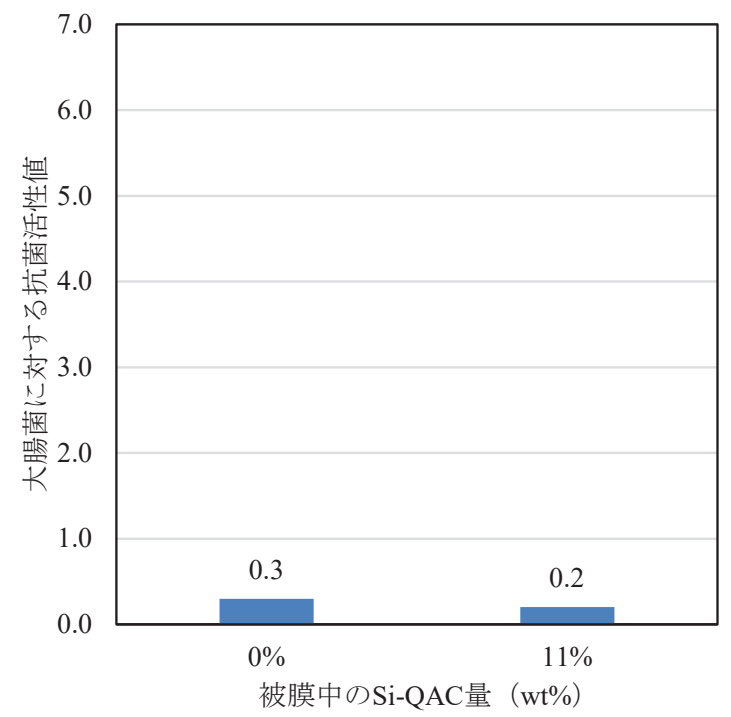

図４オリゴマーB を用いて加工したガラスパネルの 大腸菌に対する抗菌性試験結果

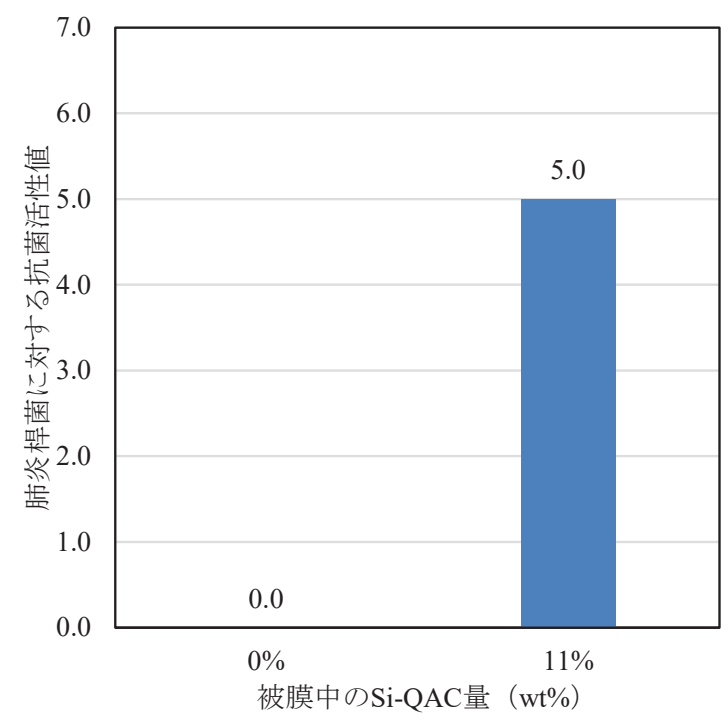

图 5 オリゴマーC を用いて加工したガラスパネルの 肺炎桿菌に対する抗菌性試験結果
QAC を固着させたステンレス表面における, 元素分布の分 析結果を図 6 および図 7 に示す。

その結果, 抗菌性に最も関与があると考えられる表層付近 を比較すると，抗菌性が得られたオリゴマーAにおいては $\mathrm{N}$ 原子と $\mathrm{Cl}$ 原子のピークが確認できるものの, オリゴマー Bにおいてはピーク強度が低い傾向であった。以上より，抗 菌剂を固着させる際の抗菌活性に対しては, 被膜中の抗菌剤 濃度に加え，バインダー成分と抗菌剤の相性も影響を及ぼす と考えられる。被膜における抗菌剤の分布や最表層の物性と 抗菌活性の関係に関しては, 今後明らかにしたいと考えている。

4. 1. 3 Si-QAC を含む被膜の機械的性質

ステンレス板に Si-QAC を固着させた被膜の機械的特性の 評価結果を表 4 に示す。また，加工時の加熱乾燥条件は $140{ }^{\circ} \mathrm{C}$ にて 20 分とし, 被膜中における Si-QAC 濃度は $11 \%$ 程度とした。

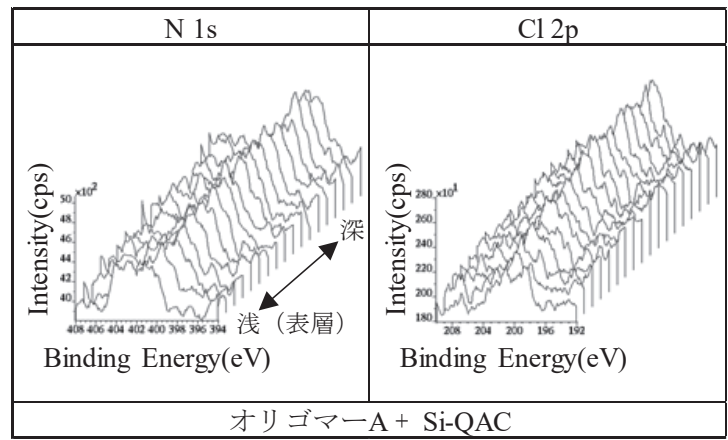

図 6 オリゴマーA + Si-QACで加工したステンレス 表面に打けるXPS 分析結果

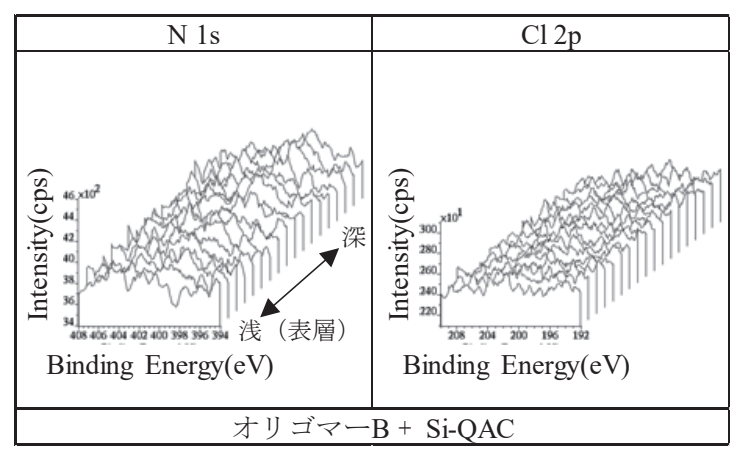

図 7 オリゴマー B + Si-QAC で加工したステンレス 表面に抢けるXPS 分析結果

表 4 Si-QAC を含む被膜の機械的性質

\begin{tabular}{|c|c|c|c|c|c|}
\hline \multirow{2}{*}{\multicolumn{2}{|c|}{ 評価項目 }} & \multicolumn{4}{|c|}{ 表面処理剂 } \\
\hline & & A のみ & $\begin{array}{c}\mathrm{A}+ \\
\text { Si-QAC }\end{array}$ & $\mathrm{C}$ のみ & $\begin{array}{c}\mathrm{C}+ \\
\text { Si-QAC }\end{array}$ \\
\hline \multicolumn{2}{|c|}{ テープ剥離試験 } & $100 / 100$ & $100 / 100$ & $100 / 100$ & $0 / 100$ \\
\hline \multicolumn{2}{|c|}{ 鉛筆硬度試験 } & $8 \mathrm{H}$ & $4 \mathrm{H}$ & $8 \mathrm{H}$ & $5 \mathrm{~B}$ \\
\hline \multirow[t]{3}{*}{ 耐摩耗性 } & $\begin{array}{l}\text { 乾ガーゼ } \\
800 \text { 回 }\end{array}$ & 剥離なし & 剥離なし & 剥離なし & 一部傷あり \\
\hline & $\begin{array}{l}\text { EtOH } \\
10 \text { 回 }\end{array}$ & 剥離なし & 剥離なし & 剥離なし & 剥離 \\
\hline & $\begin{array}{l}\text { MEK } \\
10 \text { 回 }\end{array}$ & 剥離なし & 剥離なし & 剥離なし & 剥離 \\
\hline
\end{tabular}


その結果, オリゴマー A および C は Si-QAC を配合する 前は良好な諸特性であったが, Si-QAC を加えることによって， オリゴマーCの機械的性質は低下する傾向であった。オリ ゴマーAおよびC はともに Si-QAC とシロキサン結合を形 成し得る官能基を有しているものの，オリゴマーC はオリ ゴマーA と比較して架橋点が少なく, 被膜形成に影響を及 ぼしていることが示唆される。また, 各種機械的性質の結果 より，オリゴマーAによって Si-QAC が固着された被膜は, 摩耗などの機械的ストレスに晒される環境においても抗菌効 果を維持することが期待される。

\section{2 繊維の抗菌性能について}

4. 2. 1 洗濯耐久性の向上方法の検討

表 3 で示した処理液で加工した評価材の大腸菌に対する抗 菌性評価結果を図 8 に示す。

その結果, シラン化合物 Aのみがバインダーの場合, 洗 濯 30 回後では抗菌活性が著しく低下してしまったものの, その他 3 水準においては洗濯耐久性が改善されていた。シラ ン化合物 $\mathrm{B}$ やシラン化合物 C を配合したことにより, 飛躍 的に銀成分を固着する能力が向上したと考えられる。また, 架橋剂を添加して洗濯耐久性が向上したことに関して, 詳細 なメカニズムは明らかになっていないが，架橋剤が銀成分と シラン化合物の結合を促進し, 固着能力が向上する可能性が 示唆された。

\section{2.2 銀成分およびバインダー量の最適化検討}

図 8 より，洗濯耐久性向上に対して，銀成分とバインダー 成分の量比が重要であることが示唆された。そのため, 処理 液 $\mathrm{a}$ における銀成分 + シラン化合物 $\mathrm{A}$ の濃度に対し, シラ ン化合物 B を加えた際の洗濯耐久性を，大腸菌に対する抗 菌性で評価した結果を図 9 に示す。

その結果，少なくとも $0.25 \%$ 以上のシラン化合物 B を配 合することにより洗濯 30 回後も良好な抗菌性を発現してい ることが分かる。

また，図 9 におけるシラン化合物 B の濃度 $0.50 \%$ の水準 において，被膜中の銀成分濃度が $0.30 \%$ および $1.40 \%$ とな る場合の大腸菌に対する抗菌性評価結果を図 10 に示す。

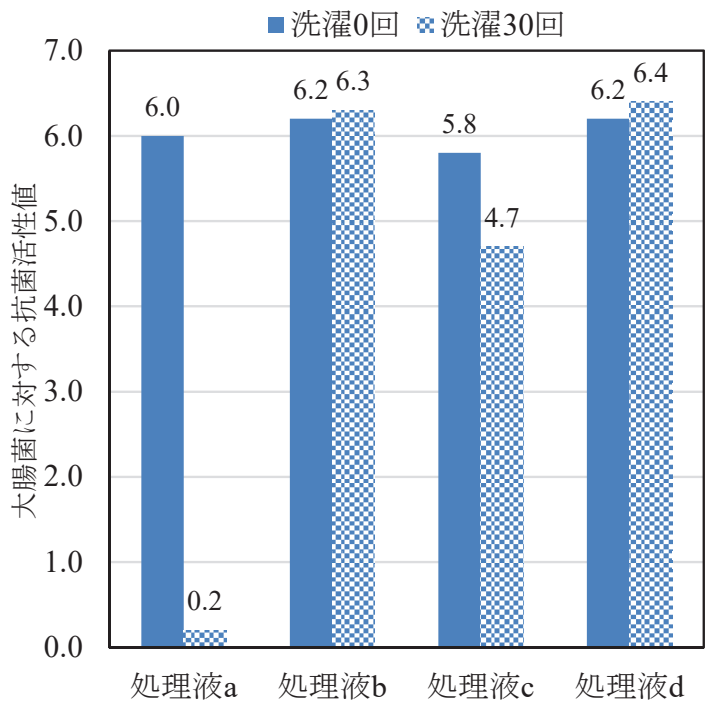

図８＼cjkstart銀成分で加工したポリエステル布の洗濯耐久性
その結果，銀成分濃度が $1.40 \%$ である水準においては，洗 濯前後で同等の抗菌活性を示していたが，0.30\%の水準にお いては洗濯後のみ抗菌活性を示す結果となった。これは，銀 成分は抗菌活性を有する状態で固定化されていたものの，洗 濯 0 回時点では被膜内の最表層に十分量分布していなかった 可能性を示唆している。また，洗濯処理によって抗菌活性が 強くなることから, 洗濯処理中に過剩なシラン化合物が繊維 上から脱落し, 銀成分の露出量が増えていることも示唆される。

以上より，繊維の表面処理においても，硬質表面を処理す る場合と同様，最表層における抗菌剂の割合が抗菌活性に影 響していると考えられる。

\section{5. おわりに}

硬質に対して，オリゴマーA と Si-QAC を含む被膜は，良 好な抗菌活性を示し， かつ，機械的な耐久性を有する結果が 得られた。これらの検討より，持続的な抗菌活性を示す表面 処理技術においては，以下の点を適切に設計する必要性が示

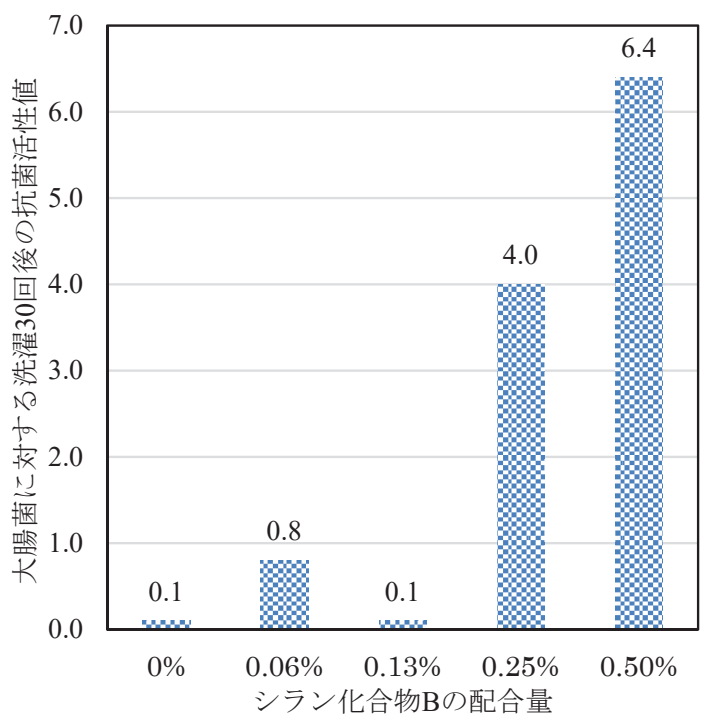

図 9 バインダー量と洗濯耐久性の関倸

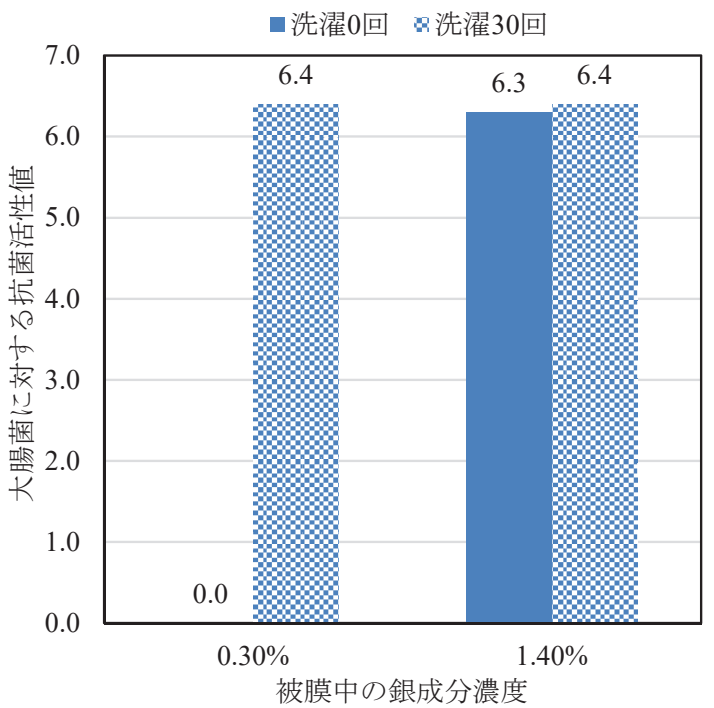

図 10 被膜中の銀成分濃度と抗菌活性の関係 
唆された。

(1) 抗菌剂と被膜構成成分の量比

(2) 抗菌剂の抗菌活性を失活させない被膜構成成分の選定

(3) 被膜の機械的耐久性を著しく損ねない抗菌剤と被膜構成 成分の組み合わせ

繊維の加工技術検討においては，上記(1)および(3)に該当 する結果が得られているものの, 今後の開発においては (2) の観点も考慮していくべきと考えられる。

今後は, 異なる抗菌剂を固着させた際の抗菌活性, 耐摩耗 性や耐水性など様々な観点での耐久性評価を行うと共に, 上 記 3 点を含めた被膜の耐久性および抗囷性を支配する因子を
把握していくことで, 活用製品に求められる抗菌性・耐久性 に応じた柔軟な表面処理技術の開発を可能としていきたい。

(Received March 25, 2021)

\section{文献}

1 ) 高麗寛紀; 化学と生物, 26, (12), 834 (1988).

2 ）鈴木亮佑, 望月太郎, 徳江 大 ; 日本パーカライジング技報, 32 , 37 (2020).

3 ）河合 博；カップリング剂の最適選定および使用技術・評価法 p.242（技術情報協会, 1998）.

4 ) 高麗寛紀; 表面科学, 22, (10), 663 (2001). 